\title{
Leptin and IGF-I improve bovine embryo quality in vitro
}

\author{
Abdullah Kaya ${ }^{1,2,5}$, Hakan Sağirkaya ${ }^{3}$, Müge Misirlioğlư ${ }^{4}$, Ahmet Gümen ${ }^{3}$, John J. Parrish ${ }^{1}$, Erdoğan Memili ${ }^{4,5}$ \\ ${ }^{1}$ Department of Animal Science, University of Wisconsin, Madison, WI, USA. \\ ${ }^{2}$ Department of Reproduction \& AI, Faculty of Veterinary Medicine, University of Selçuk, Konya, Turkey. \\ ${ }^{3}$ Department of Reproduction \& AI, Faculty of Veterinary Medicine, University of Uludağ, Bursa, Turkey. \\ ${ }^{4}$ Department of Animal and Dairy Sciences, Mississippi State University, Mississippi State, MS, USA.
}

\begin{abstract}
The in vitro embryo culture systems need further improvement to enhance the efficiency of bovine embryo production. Growth factors play key roles in embryo production and quality. The objective of this study was to define the effects of leptin, insulin-like growth factor-1 (IGF-1), and their combination on embryonic development, apoptosis, and expression profiles of a panel of developmentally important genes during 8-day embryo culture. The oocytes were aspirated from slaughterhouse ovaries of mixed breed cows. Following IVM/IVF presumptive zygotes were obtained. To accomplish this objective, presumptive zygotes (16-18 $\mathrm{h}$ post-insemination) were cultured in vitro as control (no supplementation, $\mathrm{n}=349$ ), $5 \mathrm{ng} / \mathrm{ml}$ leptin (Group I, $\mathrm{n}=322$ ), $100 \mathrm{ng} / \mathrm{ml}$ IGF-1 (Group II, $\mathrm{n}=347$ ), and $5 \mathrm{ng} / \mathrm{ml}$ leptin and $100 \mathrm{ng} / \mathrm{ml} \mathrm{IGF-1}$ (Group III, $\mathrm{n}=360$ ). All groups were supplemented with $10 \%$ fetal calf serum (FCS) on Day 4, and blastocysts were harvested on day 8. The DNAfragmented nuclei of blastocyst were determined by terminal deoxynucleotidyl transferase dUTP nick end labeling (TUNEL) assay and expression profiles of a panel of developmentally important genes were assayed by real-time polymerase chain reaction (RT-PCR). The cleavage rate and embryo development to 8-16 cell stage were higher in groups II and III as compared to control $(\mathrm{P}<0.05)$, respectively. Percentage of blastocyst and mean cell numbers per blastocyst did not differ among the groups. Addition of IGF-I and/or combination with leptin decreased the number of nuclei with fragmented DNA $(\mathrm{P}<0.01)$ as compared to the control group. Although the expression of glucose transporter 1 (Glut1), desmosomal glycoprotein desmocollin III (DcIII), and insulin like growth factor 2 receptor (Igf2r) transcripts did not change among the groups, interferon-tau (IF-tau) and DNA methyltransferase 3A (Dnmt3a) were down-regulated in group II while heat shock protein-70 (Hsp70) and IF-tau were up regulated in group III. Results indicate that addition of IGF-I in culture media improved the cleavage rate; combination with leptin also improved the development rates to 8-16-cell-stage embryos, decreased the TUNEL-positive nuclei, and caused alterations in the amounts of transcripts for the developmentally important genes assayed.
\end{abstract}

Key words: bovine, preimplantation development, apoptosis, leptin, IGF-I.

\section{Introduction}

The developmental potential of in vitro produced embryos depends on the presence of adequate regulatory proteins, growth factors and hormones in the embryo culture media as well as oocyte maturation media for improving the quality of embryos similar to their in vivo counterparts. Although many growth factors have been supplemented to the culture media to mimic the in vivo physiological environment, some other factors may still exist in female reproductive tract which possibly affect the quality of in vitro produced embryos. Recent studies have suggested that leptin, a $16-\mathrm{kDa}$ cytokine primarily secreted by adipose tissues and many tissues of the female reproductive system, plays numerous important roles in reproduction and development such as; oocyte maturation in bovine (Boelhauve et al., 2005; Jia et al., 2012) and buffalo (Panda et al., 2017) and, embryo development in porcine (Craig et al., 2005), cattle (Jia et al., 2012), buffalo (Panda et al., 2017), mice, and sheep (Herrid et al., 2006). Leptin plays a role in modulation of ovarian steroidogenesis in ruminants (Kendall et al., 2004), as well as in regulation of food intake, energy expenditure and metabolism (Barb, 1999). Cioffi et al. (1997) demonstrated that leptin was expressed at the mRNA and protein levels in the pre-ovulatory follicle, and showed the presence of leptin in mature human oocytes. In the same study, it was found that the serum concentration of leptin increased during the postovulatory period which could be associated with a higher potential for pregnancy in humans. These studies have implicated that leptin is available, and it could directly act as a modulator of biological effects on mammalian oocytes and preimplantation embryos. However, the direct roles of leptin in in vitro bovine embryo culture system have not been studied in detail.

Supplementation of leptin into culture medium has positive effects on the in vitro growth of sheep preantral ovarian follicles (Kamalamma et al., 2016). Khaki et al. (2014) reported improvement in in vitro maturation of Buffalo oocytes when cultured in media containing leptin. It has been well documented that adding $100 \mathrm{ng} / \mathrm{ml}$ IGF-I to the culture media improved bovine preimplantation embryo development (Prelle et al., 2001; Block et al., 2003). Moreover, Jousan and Hansen (2004) indicated that IGF-I can serve as a survival factor for preimplantation bovine embryos exposed to heat shock by reducing the effects of heat shock on development and apoptosis. It has been 
previously reported that addition of Insulin-like growth factor (IGF-I), a well-known growth factor, to culture medium increased embryonic development in vitro (Prelle et al., 2001). Furthermore, embryos cultured in the presence of IGF-I have better survival following transfer to recipient cows (Block et al., 2003). However, neither the mechanisms by which IGF-I increases embryonic survivability following transfer, nor the gene expression changes caused by IGF-I have been studied in detail. Defining the expression patterns of the developmentally important genes specifically involved in preimplantation development could be an important tool in selecting markers for determining embryo quality as well as the optimizing in vitro culture systems.

This study was aimed at defining the effects of leptin, insulin-like growth factor-I (IGF-I), and their combination on embryonic development, apoptosis, and expression profiles of a panel of developmentally important genes in bovines. Our results showed that addition of IGF-I in culture media improved the cleavage rate; combination with leptin also improved the development rates to 8-16-cell-stage embryos, decreased the number of TUNEL-positive nuclei, and altered expression of some of the developmentally important genes.

\section{Materials and methods chemicals and culture media}

All chemicals were purchased from Sigma Chemical Company (St. Louis, MO, USA) unless otherwise stated.

The synthetic oviduct fluid (SOF) (Specialty Media, Phillipsburg, NJ, USA) were used as a base media for embryo culture. The mouse recombinant leptin (Sigma, St. Louis, MO, USA) was dissolved in cell culture media (DMEM) to make a $10 \mu \mathrm{g} / \mathrm{ml}$ stock solution, aliquoted and stored at $-80^{\circ} \mathrm{C}$. The recombinant analog of human IGF-I was dissolved in the SOF, embryo culture media, to make a $100 \mathrm{ng} / \mu \mathrm{l}$ stock solution and aliquots were stored at $-80^{\circ} \mathrm{C}$ for up to three months.

\section{In vitro maturation (IVM) and fertilization (IVF)}

The procedures for in vitro maturation and fertilization were performed as previously described (Sagirkaya et al., 2006). Briefly, bovine ovaries were obtained from a slaughterhouse and oocytes from 2-8 $\mathrm{mm}$ diameter follicles were aspirated with 18-gauge needle. Only oocytes with several layers of cumulus cells and homogenously granulated cytoplasm were selected and washed three times in tyrode's lactate- 4-(2hydroxyethyl)-1-piperazineethanesulfonic acid (TLHEPES). Oocytes were matured in tissue culture medium (TCM-199, Gibco/Invitrogen, Grand Island, $\mathrm{NY}$ ) supplemented with $0.2 \mathrm{mM}$ pyruvate, $0.5 \mu \mathrm{g} / \mathrm{ml}$ follicle stimulating hormone (FSH;Sioux Biochemicals, Sioux City, IA), $5 \mu \mathrm{g} / \mathrm{ml}$ luteinizing hormone (LH;Sioux Biochemicals, Sioux City, IA), 10\% fetal calf serum (FCS, Gibco/Invitrogen, Grand Island, NY),
$100 \mathrm{U} / \mathrm{ml}$ penicillin and $100 \mu \mathrm{g} / \mathrm{ml}$ streptomycin (Gibco/Invitrogen, Grand Island, NY) in $50 \mu \mathrm{l}$ maturation drops (10 oocytes/drop) covered with mineral oil at $39^{\circ} \mathrm{C}$ in a humidified incubator with $5 \%$ $\mathrm{CO}_{2}$ for 24 hours. Matured oocytes were washed three times in TL-HEPES and groups of 10 oocytes were transferred to $44 \mu \mathrm{l}$ fertilization drops (glucose-free TALP supplemented with $0.2 \mathrm{mM}$ pyruvate, $6 \mathrm{mg} / \mathrm{ml}$ fatty acid free BSA, $100 \mathrm{U} / \mathrm{ml}$ penicillin and $100 \mu \mathrm{g} / \mathrm{ml}$ streptomycin) covered with mineral oil. Motile sperm were separated from cryopreserved sperm of a previously tested bull using percoll gradient and was diluted to $50 \times 10^{6}$ sperm cells $/ \mathrm{ml}$ to fertilize the matured oocytes as described previously (Parrish et al., 1995). Fertilization drops $(50 \mu \mathrm{l})$ were supplemented with $2 \mu \mathrm{l}$ diluted sperm, $2 \mu \mathrm{l}$ of $5 \mu \mathrm{g} / \mathrm{ml}$ heparin and 2 $\mu \mathrm{l}$ of PHE solution $(20 \mu \mathrm{M}$ penicillamine, $10 \mu \mathrm{M}$ hypotaurine, $1 \mu \mathrm{M}$ epinephrine) into the $44 \mu \mathrm{l}$ fertilization drops.

\section{In vitro embryo culture (IVC)}

Following 16-18 h co-culture of oocytes and sperm, cumulus cells were removed by vortexing the presumptive zygotes in a $1.5 \mathrm{ml}$ Eppendorf tube for three minutes. The cumulus free presumptive zygotes were washed three times in TL-HEPES and assigned to one of four culture conditions. We investigated the putative effects of adding $5 \mathrm{ng} / \mathrm{ml}$ leptin and $100 \mathrm{ng} / \mathrm{ml}$ IGF-I to culture media. The concentration of IGF-I at $100 \mathrm{ng} / \mathrm{ml}$ was chosen for the results previously shown to improve embryonic development (Prelle et al., 2001; Block et al., 2003). The SOF media was used as a base culture media for supplements using $2 \times 2$ factorial designs: control (no supplement), leptin ( $5 \mathrm{ng} / \mathrm{ml})$, IGFI $(100 \mathrm{ng} / \mathrm{ml})$ and leptin + IGF-I $(5 \mathrm{ng} / \mathrm{ml}$ Leptin +100 $\mathrm{ng} / \mathrm{ml}$ IGF-I) treatments. Twenty-five cumulus free presumptive zygotes were transferred into a $50 \mu \mathrm{l}$ drops under mineral oil for corresponding treatments and $10 \%$ FCS was added to each drop on day 4. Fertilization time in the present study was considered as 0 hour. Developmental data were recorded for 2-cell, 8-16 cell, and blastocyst (2 times) stage embryos at 48, 96, 168 and 192 hours' post insemination (hpi), respectively. Total of 349, 322, 347 and 360 zygotes were used for control, leptin, IGF-I, leptin+IGF-I groups, respectively in total of six replicates. Day 8 (192 hpi) blastocysts were removed from culture drops and washed four times with TL-HEPES with polyvinylpyrrolidone (PVP) (3 $\mathrm{mg} / \mathrm{ml})$. Then the blastocysts were randomly assigned (groups of five) and either fixed in $4 \%$ paraformaldehyde for determination of blastocyst cell number and number of apoptotic nuclei by TUNEL assay, or frozen in $0.9 \%$ sodium chloride $(\mathrm{NaCl})$ for the gene expression level of developmentally important genes in preimplantation embryos.

\section{Detection of blastocyst cell number and DNA fragmentation}

In order to determine average cell numbers and percentages of fragmented DNA, the TUNEL assay was 
applied using the DeadEnd ${ }^{\mathrm{TM}}$ Fluorometric Apoptosis Detection Kit (Promega, Madison, WI) as described before (Fedorcsák and Storeng, 2003; Sagirkaya et al., 2006). Briefly, blastocysts were removed from culture media and washed three times in $100 \mu \mathrm{l}$ drops of $1 \%$ PVP in PBS, and then fixed with $4 \%$ formaldehyde for approximately $1 \mathrm{~h}$. Fixed embryos were stored at $4^{\circ} \mathrm{C}$ until the TUNEL assay was performed. On the day of the TUNEL assay, the embryos were transferred from $4^{\circ} \mathrm{C}$ to room temperature and washed three times in $100 \mu \mathrm{l}$ drops of $1 \%$ PVP in PBS and then permeabilized in $50 \mu \mathrm{l}$ of $0.5 \%$ Triton $\mathrm{X}-100$ for $30 \mathrm{~min}$ at room temperature in a humidified chamber and rinsed twice in PBS. Then, the embryos were incubated with $100 \mu \mathrm{l}$ of DNAse buffer for $5 \mathrm{~min}$. Meanwhile, $100 \mu \mathrm{l}$ of DNAse buffer containing DNAse I $(20 \mathrm{U} / \mathrm{ml})$ was added to the embryos previously assigned as positive and negative controls for TUNEL assay, and $100 \mu \mathrm{l}$ DNAse buffer was added to the other embryos. All embryos were incubated at $37^{\circ} \mathrm{C}$ for $30 \mathrm{~min}$, and then they were washed four times with $100 \mu$ of double distilled water by transferring embryos from one drop to another. Thereafter, the embryos were exposed to $100 \mu \mathrm{l}$ equilibration buffer for $10 \mathrm{~min}$. Subsequently, 10 embryos were transferred into $50 \mu \mathrm{l}$ of prepared rTdT reaction buffer ( $45 \mu \mathrm{l}$ of equilibration buffer, $5 \mu \mathrm{l}$ of nucleotide mix and $1 \mu \mathrm{l}$ of rTdT enzyme). For negative control slides, rTdT enzyme was replaced with $1 \mu \mathrm{l}$ autoclaved deionized water. All embryos were incubated for $1 \mathrm{~h}$ at $37^{\circ} \mathrm{C}$ in the dark. The reaction was terminated by incubating the embryos with 2XSSC solution for $15 \mathrm{~min}$ at room temperature and then they were washed twice in PBS. The embryos were then incubated with RNase A $(50 \mu \mathrm{g} / \mathrm{ml})$ in Tris $(10 \mathrm{mM}$, $\mathrm{pH}=7.5)$ and $\mathrm{NaCl}(15 \mathrm{mM})$ for $40 \mathrm{~min}$ at $37^{\circ} \mathrm{C}$. Finally, embryos were stained with propidium iodide $(1 \mu \mathrm{g} / \mathrm{ml})$ for $15 \mathrm{~min}$ and washed with deionized water to remove excess stain. After the last wash, the embryos were mounted with an antifade solution (DABCO) and covered with a coverslip for evaluation. Assessment of TUNEL-positive and total cell numbers was accomplished by evaluating each embryo under an epifluorescent microscope (Nikon, Japan) equipped with a $450-490 \mathrm{~nm}$ excitation filter, a 520-nm barrier emission filter and a $520 \mathrm{~nm}$ dichroic mirror, using a 40x objective. The apoptotic nuclei with fragmented DNA were observed as yellowish-green, while normal nuclei appeared as an orange-red color. Total of 38, 44, 33 , and 45 blastocysts were used for total cell number and TUNEL assay for control, leptin, IGF-I and leptin + IGF-I groups, respectively.

\section{Isolation of total RNA and cDNA synthesis}

In vitro produced blastocysts were first transferred into TL-HEPES from culture media and groups of five blastocysts were rinsed three times in $0.9 \% \mathrm{NaCl}$, and finally transferred into $500 \mu \mathrm{l}$ centrifuge tubes with a minimal amount of saline and were kept at $-80^{\circ} \mathrm{C}$ until RNA isolation. Total RNA was isolated from a pool of five in vitro produced blastocysts (six repeats) using an RNeasy Micro Kit (Qiagen, Valencia, CA) according to the manufacturer's instructions and treated with DNAse. Quality and quantity of total RNA isolated from blastocysts were estimated using a Bioanalyzer 2100 RNA 6000 picochip kit (Agilent, Palo Alto, CA). Total RNA (8 ng) was used for cDNA synthesis using the first strand cDNA synthesis kit for RT-PCR (AMV, Roche Applied Sciences, IN) according to the manufacturer's protocol. Samples were incubated for $10 \mathrm{~min}$ at $25^{\circ} \mathrm{C}, 60 \mathrm{~min}$ at $42^{\circ} \mathrm{C}$ and then at $99^{\circ} \mathrm{C}$ for $5 \mathrm{~min}$.

\section{Primer and TaqMan probes and real-time PCR}

All PCR primers and probes were designed using Primer Premier 5 software (Premier Biosoft International, Palo Alto, CA). The sequences and positions of the primers and TaqMan probes used the fragment size and the sequence references of the expected PCR products are shown in Table 1.

Real-time quantitative PCR was performed to assess transcripts of glucose transporter-1 (Glut-1), heat shock protein 70 (Hsp70), interferon tau (IF- $\tau$ ), DNA methyltransferase $3 \mathrm{a}$ (Dnmt3a), desmosomal glycoprotein desmocollin III (DcIII), and insulin-like growth factor II receptor (Igf-2r) relative to housekeeping gene GAPDH. Each cDNA sample was analyzed in duplicate using the LightCycler instrument (Roche Applied Sciences, Indianapolis, IN) as described previously (Sagirkaya et al., 2006). Quantitative assessment of RNA amplification was detected with the TaqMan probes, which were specific for the targeted genes. The TaqMan probe contains 2 dyes, a reporter and a quencher dye, the primers were fluorescence labeled at the 5' end with 6-carboxyfluorescein (FAM) as a reporter dye and at the 3' end with 6carboxytetramethylrhodamine (TAMRA) as the quencher (Tibmolbiol, Adelphia, NJ). The real-time PCR reactions were carried out in a total volume of 10 $\mu 1$ according to the manufacturer's manuals for Hybridization Probes Master mix (Roche Applied Sciences, Indianapolis, IN). The primers and TaqMan probe concentrations were $0.3 \mu \mathrm{M}$ and $0.2 \mu \mathrm{M}$, respectively. The cycling parameters were 2 minutes at $95^{\circ} \mathrm{C}$ for denaturation, 50 cycles of 5 seconds at $95^{\circ} \mathrm{C}$, 20 seconds at $60^{\circ} \mathrm{C}$ for amplification and quantification. Amounts of transcripts were determined relative to that of glyceraldehyde 3-phosphate dehydrogenase (GAPDH). In real time RT-PCR reactions the same initial amounts of target molecules were used, and the $\mathrm{Cp}$ values $(22.90 \pm 0.02)$ of GAPDH mRNA were constant in all in vitro and in vivo groups. Software named relative expression software tool (REST) was used, and compared all samples of each group. The mathematical model used is based on the PCR efficiencies and the crossing point deviation between the samples (Pfaffl et al., 2002). 
Table 1. Sequences of Real Time PCR primers and TaqMan probes.

\begin{tabular}{|c|c|c|c|}
\hline Genes & $\begin{array}{l}\text { Primer and TaqMan probe sequences and positions } \\
\qquad\left(5^{\prime} \rightarrow 3^{\prime}\right)\end{array}$ & $\begin{array}{l}\text { Fragment } \\
\text { size }(b p)\end{array}$ & $\begin{array}{c}\text { Sequence } \\
\text { references } \\
\text { (Accession no.) }\end{array}$ \\
\hline $\begin{array}{l}\text { Glucose transporter-1 } \\
\text { (Glut-1) }\end{array}$ & $\begin{array}{l}\text { CCAAGGATCTCTCAGAGCACAG } \\
(1688-1709) \\
\text { TTCTTCTGGACATCACTGCTGG } \\
(1797-1776) \\
\text { FAM-GATAGATCTCAGCAGAGCCGGGCCT- } \\
\text { TAMRA } \\
(1734-1758)\end{array}$ & 110 & M60448 \\
\hline $\begin{array}{l}\text { Heat shock protein } 70 \\
\text { (Hsp } 70)\end{array}$ & $\begin{array}{l}\text { GACAAGTGCCAGGAGGTGATTT } \\
(1870-1891) \\
\text { CAGTCTGCTGATGATGGGGTTA } \\
(1986-1965) \\
\text { FAM-AGCACAAGAGGAAGGAGCTGGAGCA- } \\
\text { TAMRA } \\
(1934-1958)\end{array}$ & 117 & U09861 \\
\hline Interferon tau (If- $\tau)$ & $\begin{array}{l}\text { TCCATGAGATGCTCCAGCAGT } \\
(433-453) \\
\text { TGTTGGAGCCCAGTGCAGA } \\
(535-517) \\
\text { FAM-AGCACTCGTCTGCTGCCTGGAACA- } \\
\text { TAMRA } \\
(475-498)\end{array}$ & 103 & X65539 \\
\hline $\begin{array}{l}\text { DNA } \\
\text { methyltransferase } 3 a \\
\text { (Dnmt3a) }\end{array}$ & $\begin{array}{l}\text { TGATCTCTCCATCGTCAACCCT } \\
\text { (2062-2083) } \\
\text { GAAGAAGGGGCGGTCATCTC } \\
(2185-2166) \\
\text { FAM-TGAGTTCTACCGCCTCCTGCATGATG- } \\
\text { TAMRA } \\
(2125-2150)\end{array}$ & 124 & AY271298 \\
\hline $\begin{array}{l}\text { Desmocollin III } \\
\text { (DcIII) }\end{array}$ & $\begin{array}{l}\text { CCTCTGTGATTGTACTAACCCCG } \\
(2006-2028) \\
\text { GAAGTATGGCAAGGATCGCC } \\
\text { (2078-2097) } \\
\text { FAM- TGCTCGACGGAGTGCGGACGT-TAMRA } \\
(2042-2062)\end{array}$ & 92 & L33774 \\
\hline $\begin{array}{l}\text { Insulin-like growth } \\
\text { factor } 2 \text { receptor (Igf- } \\
2 \text { r) }\end{array}$ & $\begin{array}{l}\text { CAGGTCTTGCAACTGGTGTATGA } \\
\text { (4935-4957) } \\
\text { TTGTCCAGGGAGATCAGCATG } \\
(5071-5051) \\
\text { FAM-AAGAGCGTCATCAGCTTCGTGTGCA- } \\
\text { TAMRA } \\
(4998-5022)\end{array}$ & 137 & J03527 \\
\hline $\begin{array}{l}\text { Glyceraldehyde-3- } \\
\text { phosphate } \\
\text { dehydrogenase } \\
\text { (GAPDH) }\end{array}$ & $\begin{array}{l}\text { AAGGCCATCACCATCTTCCA } \\
(178-197) \\
\text { CCACTACATACTCAGCACCAGCAT } \\
(253-230) \\
\text { FAM-AGCGAGATCCTGCCAACATCAAGTGG- } \\
\text { TAMRA } \\
(200-225)\end{array}$ & 76 & U85042 \\
\hline
\end{tabular}

Statistical analysis

The percentage of embryos reaching a given stages of development were determined from the number of presumptive zygotes. The arcsine square root transformed data were analyzed with a randomized complete block design (RGB) using SAS mixed procedure to determine the significant differences among the groups. Significant differences of blastocyst cell number and the proportion of fragmented DNA (TUNEL positive nuclei) per blastocyst (arcsine square root transformed data) were determined by using one-way analysis of variance (ANOVA). Differences at $\mathrm{P}<0.05$ were considered significant. The software used for statistical analyses was SAS Online version 8.2 (SAS Institute Inc., Cary, NC). 
Statistical analysis of gene expression patterns of the developmentally important genes was performed by using relative expression software tool REST $^{\odot}, 384$ beta version May 2005), which runs in Microsoft Excel. The software combined gene quantification and normalization into a single calculation. $\operatorname{REST}^{\odot}$ is based on an efficiency corrected mathematical model for data analysis. It calculates the relative expression ratio on the basis of the PCR efficiency (E) and crossing point deviation $(\triangle \mathrm{CP})$ of the investigated transcripts and on a newly developed randomization test macro. REST $^{\odot}$ uses the pair wise fixed reallocation randomization test to calculate significance of the results (Pfaffl, 2001; Pfaffl et al., 2002; Sagirkaya et al., 2006). Differences at $\mathrm{P}<0.001$ were considered significant. The software used for statistical analyses is an established method and analyzes real time PCR results directly.

\section{Results}

Effect of leptin and IGF-I on embryo development in vitro

To demonstrate the effect of leptin and IGF-I on embryonic development, we cultured presumptive zygotes in SOF medium with these supplements alone or in combination. Results are exhibited in Figure 1. While leptin alone did not increase any of the embryo development stages tested in this study, IGF-I alone improved percent cleaved embryos at $48 \mathrm{hr}$ post insemination (hpi) compared to control $(\mathrm{P}<0.05,87 \mathrm{vs}$. $79 \%$, IGF-I vs. control). However, when we supplemented the culture medium with both leptin and IGF-I together, development of embryos to 8-16 cell stages was improved significantly $(\mathrm{P}<0.05,51$ vs. $44 \%$, Leptin+IGF-I $v s$. control). This suggests that when combined these two supplements help embryos undergo embryonic genome activation (EGA) successfully at early stage. The proportion of embryos reached to blastocyst stage on day 8 were 26.7, 29.6, 31.5 and 29.8 for control, leptin, IGF-I, leptin+IGF-I groups, respectively. Although there was a numerical increase in blastocyst formation on day 8 , neither leptin, IGF-I alone nor combination resulted in any significant improvement $(\mathrm{P}>0.05)$.

\section{Effect of leptin and IGF-I on blastocyst cell number and DNA fragmentation}

The purpose of this experiment was to determine whether leptin and IGF-I alone or in combination enhances developmental capacity of bovine embryos by increasing total cell number and reducing DNA fragmentation, a sign of apoptosis. The mean cell numbers of the blastocysts were similar (97-104 cells per blastocysts) in all groups and were not different (Figure 2A). However, the same blastocysts which were used for blastocyst cell number assay have had reduced incidence of TUNEL-positive blastomers in IGF-I $(\mathrm{P}<0.01)$ and leptin + IGF-I treatments $(\mathrm{P}<0.001)$ compared to control (2.2 and $1.9 v s .4 .2 \%$, IGF-I and Leptin+IGF-I $v s$. control, respectively). In the presence of leptin alone, the proportion of DNA fragmented cells was similar to control $(\mathrm{P}>0.05)$ (Figure $2 \mathrm{~B})$.
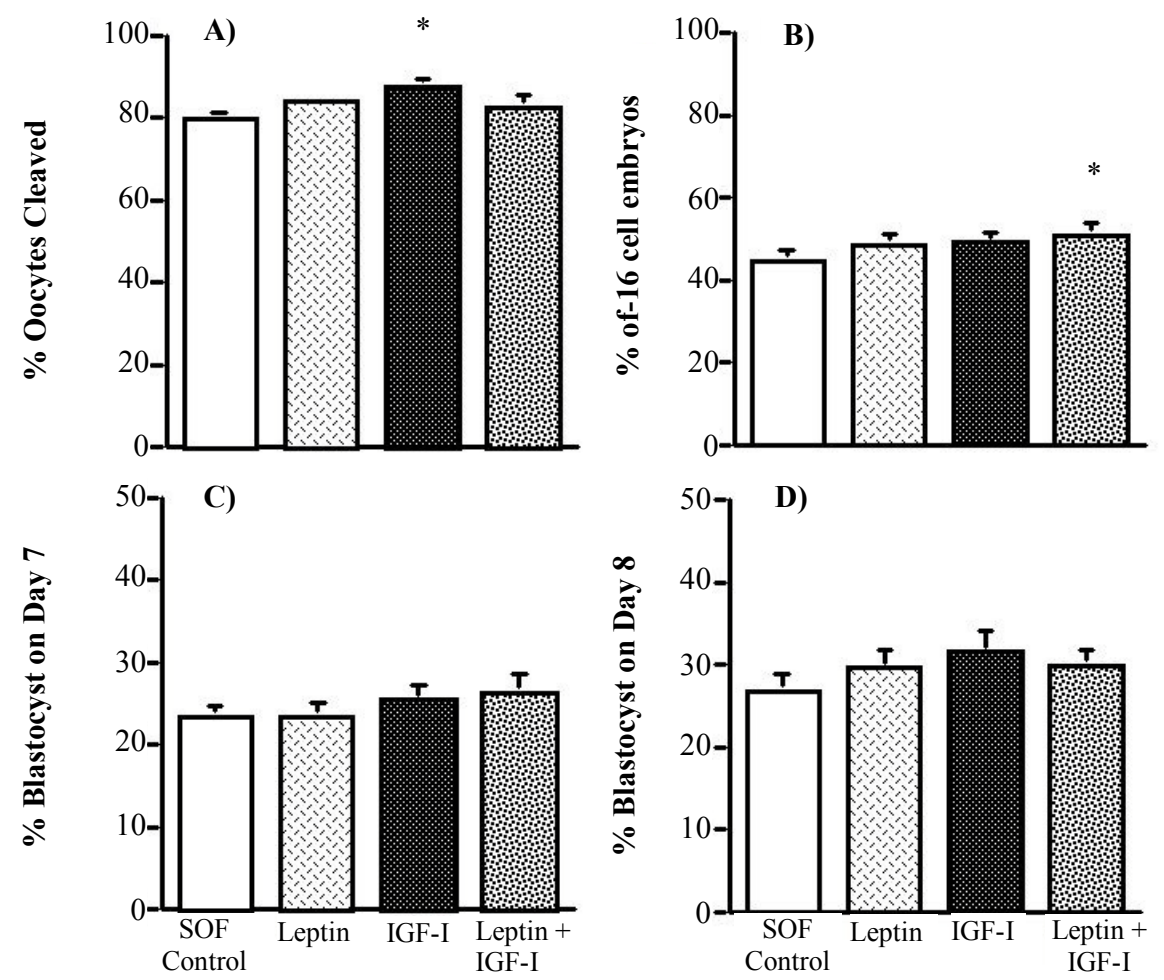

Figure 1. Effects of Leptin and IGF-I on percentage of embryos cleaved (A), developing beyond 8-16 cell stage (B), blastocyst on day 7 (C) and blastocyst on day 8 (D) of in vitro culture. Developing embryos in SOF medium were supplemented with $10 \%$ FCS on day 4 of IVC in all groups. Results are presented as the least squares mean \pm SEM of six replicates using at least 50 presumptive zygotes per replicates in Control $(\mathrm{n}=349)$, Leptin $(\mathrm{n}=322)$, IGF-I $(\mathrm{n}=347)$ and Leptin + IGF-I $(\mathrm{n}=360)$. Significant differences from the Control are indicated by $*(\mathrm{P}<0.05)$. 

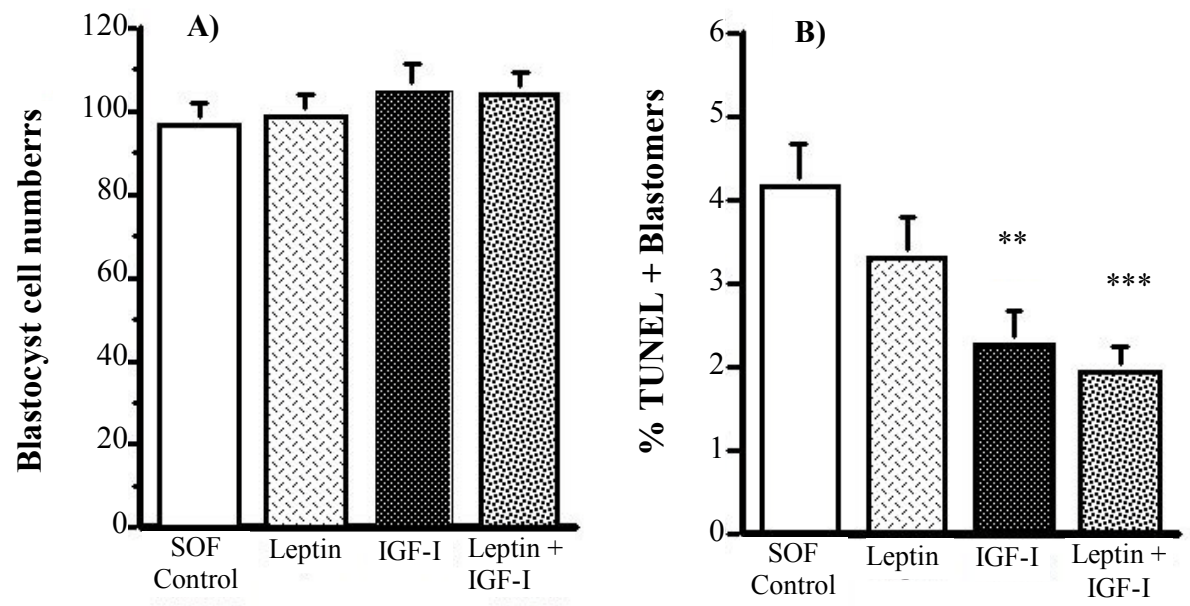

Figure 2. Effects of Leptin and IGF-I on total cell number (A), and DNA fragmentation (B) of bovine blastocyst cultured in SOF medium supplemented with 10\% FCS on day 4 of IVC in all groups. Day 8 embryos were collected from 6 replicates, and were labeled with TUNEL assay Fluorescein Apoptosis Detection kit. Total number of cells and TUNEL positive blastomers were counted in SOF Control $(n=38)$, Leptin $(n=44)$, IGF-I $(n=33)$ and Leptin + IGF-I $(n=45)$, and data represents the mean \pm SEM of evaluated embryos for corresponding treatment groups. Significant differences from the Control are indicated by $* *(\mathrm{P}<0.01)$ and $* * *(\mathrm{P}<0.001)$.

\section{Effect of leptin and IGF-I on mRNA expression of developmentally important genes}

Our next aim was to analyze transcripts of a panel of genes that play important roles in early development. In order to determine the gene expression profiles at the mRNA levels, we first assessed the integrity of total cellular RNA using Bioanalyzer (Agilent). Results shown in Figure 3 indicated that the
RNA isolated from blastocysts of all groups had intact RNA with sharp 28 and $18 \mathrm{~S}$ ribosomal RNA bands. We analyzed transcript abundances of a group of six genes, namely Glucose transporter-1 (Glut-1), heat shock protein 70 (Hsp70), interferon tau (IF- $\tau)$, DNA methyltransferase 3a (Dnmt3a), desmosomal glycoprotein desmocollin III (DcIII), and insulin-like growth factor II receptor (Igf-2r) relative to housekeeping gene GAPDH using real time RT-PCR.

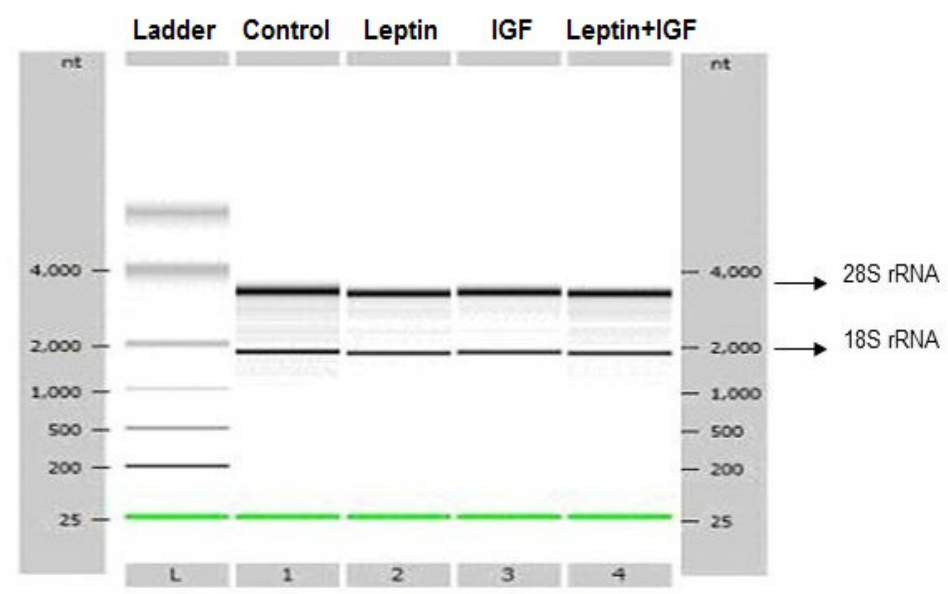

Figure 3. Total cellular RNA isolated from Control (Lane 1), Leptin (Lane 2), IGF-I (lane 3) and from Leptin+IGF-I (lane 4) was run on a Pico Chip Gel using Bioanalyzer (Agilent).

The relative abundance of hsp70 gene transcripts was up-regulated in blastocysts cultured with $5 \mathrm{ng} / \mathrm{ml}$ leptin. Although this increase was not significant compare to control $(\mathrm{P}<0.05)$, it was significant when compared to IGF-I, and leptin + IGF-I supplemented culture conditions $(\mathrm{P}<0.001)$. Additionally, the hsp70 gene was significantly downregulated in leptin + IGF-I supplementation when compared to control $(\mathrm{P}<0.001)$ (Figure 4A). Although the expression of IF-tau gene was up-regulated in leptin
$(\mathrm{P}<0.001)$ and IGF-I $(\mathrm{P}<0.001)$ addition to the culture media, when leptin and IGF-I supplemented to the culture media together, the expression level of IF-tau was surprisingly down-regulated relative to control $(\mathrm{P}<0.001)$ (Figure 4B).

The expression of Dnmt3a gene was up-regulated in IGF-I treatment relative to control $(\mathrm{P}<0.001)$. Adding leptin and combination with IGF-I did not change the relative expression of Dnmt3a gene $(\mathrm{P}>0.05)$ (Figure $4 \mathrm{C})$. The relative abundance of glucose transporter-1 
(Glut-1) (Figure 4D), desmosomal glycoprotein desmocollin III (DcIII) (Figure 4E), and insulin-like growth factor II receptor (Igf-2r) (Figure 4F) gene transcripts were similar in all treatments $(\mathrm{P}>0.05)$.
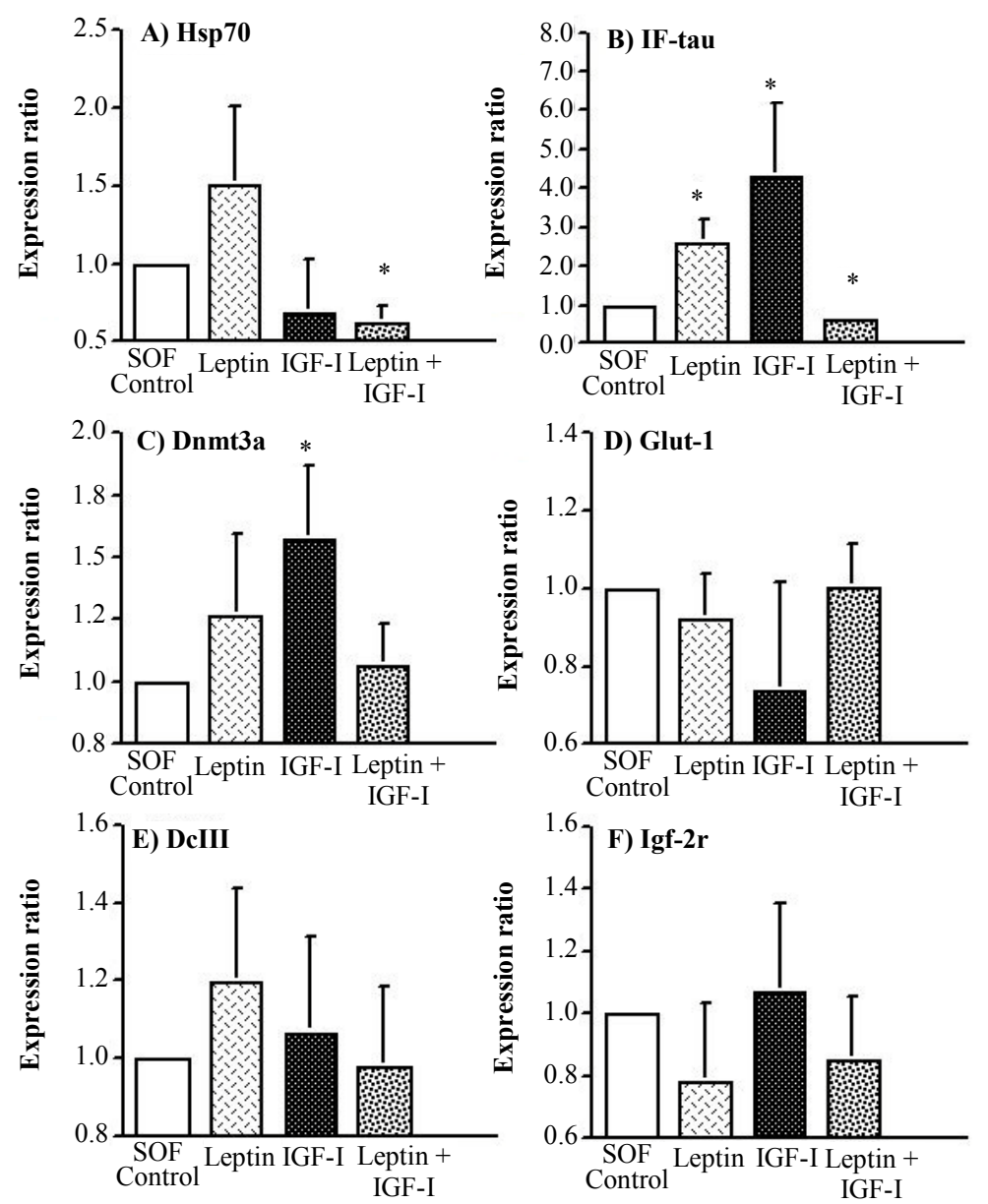

Figure 4. Effects of Leptin and IGF-I during embryo culture on the relative abundance of Hsp70 (A), IF-tau (B), Dnmt3a (C), Glut-1(D), DcIII (E) and Igf-2r (F) gene transcripts in blastocysts. Values are shown as means \pm SEM of six replicates (5 blastocyst pooled/replicate) from treatments groups: Control, Leptin, IGF-I, Leptin+ IGF-I. Significant differences from the Control are indicated by $*(\mathrm{P}<0.001)$.

\section{Discussion}

In vitro production of mammalian embryos is crucially important both in basic science to examine the developmental dynamics at the onset of life, and in accelerating genetics of agriculturally important animals. Continuing efforts on development of protocols for optimum culture conditions in in vitro embryo production have been mimicking the composition of physiological environments that early embryos pass through. This includes the presence of adequate regulatory proteins, growth factors and hormones in the culture media for improving the quality of embryos similar to their in vivo counterparts.

Leptin is a $16 \mathrm{kDa}$ protein that is believed to play important roles in mammalian reproductive physiology in vivo (Cioffi et al., 1997; Kendall et al., 2004). The physiological levels of leptin concentration have been reported to be between 1 and $10 \mathrm{ng} / \mathrm{ml}$ in the cow depending on the stage of estrus cycle (Garcia et al., 2002). Garcia et al. (2002) reported that leptin gene expression and circulating concentration of leptin and IGF-I increases in heifers as puberty approaches. Over recent years, research in many species has examined that leptin modulates oocyte maturation and preimplantation development of embryos (Kawamura et al., 2002; Fedorcsák and Storeng, 2003; Boelhauve et al., 2005; Craig et al., 2005; Herrid et al., 2006; Paula-Lopes et al., 2007; Jia et al., 2012; Panda et al., 2017). The existing evidence therefore suggests that supplementation of leptin to the culture media may improve both quality and quantity of bovine embryos in vitro. It has also been shown in the previous reports that $100 \mathrm{ng} / \mathrm{ml}$ IGF-I in the embryo culture media improved the quality of in vitro produced embryos (Prelle et al., 2001; Block et al., 2003). In this study, our objective was to examine the effects of leptin and IGF-I on the quality and quantity of the bovine embryos as well as the expression patterns of the developmentally important genes.

The present findings, that adding physiologic level of leptin to the most common embryo culture media (SOF based) and serum (10\% $\mathrm{FCS})$ added system, did not improve embryo development as compared to control. Similar results were reported in mouse embryos cultured in potassium supplementedsimplex optimized medium (KSOM) media (Swain et al., 2004) and in M16 media (Fedorcsák and Storeng, 2003). Boelhauve et al. (2005) reported that oocytes 
cultured in the presence of 1 and $10 \mathrm{ng} / \mathrm{ml}$ of leptin resulted in higher maturation rate, and subsequently blastocyst rate, but not with the addition of $100 \mathrm{ng} / \mathrm{ml}$ leptin supplementation. The logical explanation of these differences might be that the differences in the base culture media and undefined and variable composition of FCS (batch to batch differences) which was added to the culture media on day 4 of culture media. In this regard, we assume that when we added FCS during embryo culture, most likely, we have delivered enough leptin to promote embryo development already.

Arias-Alvarez et al. (2011) interpreted that the high leptin concentrations might be detrimental on preimplantation embryo development rather than being beneficial due to the consideration being related to obesity. On the other hand, van Tol et al. (2008) reported that the presence of $1,000 \mathrm{ng} / \mathrm{ml}$ leptin during maturation improved the developmental competence of the oocytes by supporting embryonic development up to the transition of maternal to embryonic genome transcription. Recently, Kšiňanová et al. (2017) reported positive effects of leptin on mouse embryo development.

Some cells undergo apoptosis or programmed cell death caused by suboptimal culture conditions during normal embryo development in vitro and it may play an important role in the elimination of the damaged, nonfunctional or abnormal cells in the developing bovine embryos (Brill et al., 1999; Byrne et al., 1999; Jousan and Hansen, 2004). The characteristic nuclear changes for early apoptotic stage include DNA fragmentation which can be detected by TUNEL assay (Byrne et al., 1999). Therefore, the determination of apoptotic index in the developing embryos can be used as an indicator of embryo quality. Byrne et al. (1999) reported that a lower incidence of apoptosis determined by TUNEL assay was found in bovine blastocysts derived from early-cleaving zygotes than those that cleaved later. The embryos with high incidence of apoptotic nuclei may most likely fail to maintain the developmental competence in vitro or in vivo (such as before or after implantation) due to the elimination of damaged cells and/or embryos via apoptotic machinery (Brill et al., 1999). Paula-Lopes et al. (2007) demonstrated that addition of $1-10 \mathrm{ng} / \mathrm{ml}$ leptin to the serum-free culture medium resulted in lower incidence of apoptotic cumulus cells.

In this study, the supplementation of $100 \mathrm{ng} / \mathrm{ml}$ of IGF-I resulted in an increase in percentage of cleaved-oocytes (Fig 1A) and when IGF-I combined with $5 \mathrm{ng} / \mathrm{ml}$ of leptin, embryos developing beyond 8 16 cell stages were also improved (Fig 1B). Contrary to the previous studies (Craig et al., 2005; Herrid et al., 2006), our results indicate that although there seems to be a numerical increase in blastocyst development on day 8 of culture, neither leptin and IGF-I alone nor combination significantly increased the percent blastocyst development (Fig 1C-D) with the given embryo culture system. However, while the mean blastocyst cell numbers were similar in all groups (Fig $2 \mathrm{~A}$ ), the percentage of DNA fragmented nuclei or apoptotic nuclei per blastocyst were lower in IGF-I ( $\mathrm{P}<$ $0.01)$ and leptin + IGF-I $(\mathrm{P}<0.001)$ supplemented groups (Fig 2 B). This shows that the IGF-I has played anti-apoptotic role and the effect has been further enhanced with the combination of Leptin. Consistent with our observations, Jousan and Hansen (2004) indicated that supplementation of $100 \mathrm{ng} / \mathrm{ml} \mathrm{IGF-I}$ protected the preimplantation embryos from detrimental effect of heat stress in terms of the incidence of apoptotic blastomers per blastocyst.

Alterations in gene expression impact preimplantation period of mammalian embryogenesis, including extensive changes in DNA methylation, chromatin structure and histone acetylation-methylation related to genomic imprinting that is able to support embryogenesis and carry out the developmental program (Latham and Schultz, 2001). It has been reported that bovine early stage embryos and blastocysts are transcriptionally active (Memili and First, 1999), and embryo culture media and conditions influence gene expression (Wrenzycki et al., 2004). Misirlioglu et al. (2006) determined panoramic picture of transcriptome in the matured bovine oocytes and in 8- to 16-cell embryos, a critical stage where major embryonic genome activation occurs. Determination of the expression patterns of developmentally important genes in regard to assessing the quality of preimplantation embryos provides valuable information for developing new strategies in improving in vitro embryo production. Consistent with previous studies (Lonergan et al., 1999; Wrenzycki et al., 2004) the data presented here on relative mRNA abundance confirm that mRNA levels of genes indicative of various physiological processes during bovine preimplantation embryo development are affected by culture conditions. Paula-Lopes et al. (2007) demonstrated that physiological leptin supplementation differentially regulates gene expression in oocytes and cumulus cells in vitro. In contrast, Arias-Alvarez et al. (2011) showed that the presence or absence of leptin did not change the expression profile of genes that are related to embryo quality.

Heat shock proteins (Hsp) play important roles in embryonic development, which exhibits over expression to protect embryos against various stress conditions in vitro (Christians et al., 1995; Wrenzycki et al., 1999; Neuber and Powers, 2000). Neuber and Powers (2000) indicate that expression of heat shock proteins are the cellular defense mechanisms which preserve cell survival under the adverse conditions such as hyperthermia, free oxygen radicals, heavy metals, ethanol, amino acid analogues, inflammation and infection. Christians et al. (1995) reported that the expression levels of HsP70.1 in in vitro produced murine embryos was higher than those of in vivo embryos which reflects the sensitivity of embryos to the suboptimal culture conditions such as temperature or free oxygen radicals. Similarly, Edwards et al. (1997) reported that Hsp70 gene expression was also upregulated in in vitro produced bovine embryos following heat stress. In the present study, surprisingly the presence of leptin and IGF-I alone in the culture media did not change the expression pattern of Hsp70 gene transcript. However, when leptin and IGF-I were supplemented together, the over expression of Hsp70 
gene was prevented (Fig 4A). This implies that these molecules have a synergic effect on the prevention of the stress factors caused by suboptimal culture conditions in vitro. Although the mechanism is unclear, it can be speculated that the IGF-I might ultimately reduce the regulation of Hsp70.1 secretion by serving as an antiapoptotic factor which compensates the deleterious consequences of in vitro culture conditions on bovine embryos.

We observed a significantly higher level of expression of IF-tau gene transcript in blastocysts derived from leptin and IGF-I supplemented embryo culture conditions $(\mathrm{P}<0.001)$ (Fig. $4 \mathrm{~B}$ ). IF-tau is the primary agent responsible for maternal recognition of pregnancy in cattle (Wrenzycki et al., 1999) which would be consistent with the notion that changes in its mRNA levels influence developmental potential. In agreement, Rizos et al. (2003) reported increased levels of IF-tau mRNA in blastocysts produced with no serum added embryo culture. Although IF-tau production is apparently independent of blastocyst cell number, it is consistent with the number of DNA fragmented nuclei which is related to the quality of blastocyst in leptin and IGF-I treatments. Therefore, embryos cultured with leptin and IGF-I might have higher in vivo survival rates when transferred to a recipient cow.

During mammalian preimplantation development, the epigenetic modification of DNA by methylation is a crucial event which is involved in a number of key roles such as imprinting, $\mathrm{X}$ chromosome inactivation, genome stability, silencing and supporting embryonic growth and cell differentiation (Kaneda et al., 2004). In bovine, the genomic methylation pattern is increased during the first few cleavage divisions. Specific methyltransferase enzymes are responsible for this increase in methylation. Kaneda et al. (2004) reported that Dnmt3a is required for establishment of both maternal and paternal imprints. In the present study, expression of the Dnmt3a gene transcripts was significantly up-regulated by the IGF-I supplementation relative to control $(\mathrm{P}<0.001)$ (Fig. 4C). From careful examination of the data reported in this study, it appears that adding IGF-I alone and combination with leptin have significant impact on in vitro embryo culture which resulted in an increase in the cleavage, the proportion of embryos passing the 8-16 cell stage and decrease in the apoptotic nuclei per embryo. This consistent improvement might be due to the proper epigenetic modifications through DNA methylation, although much stronger evidence is needed for more definitive cause and effect relationships.

In conclusion, the presence of $5 \mathrm{ng} / \mathrm{ml}$ of leptin alone in the SOF media supplemented with $10 \% \mathrm{FCS}$ on day 4 of IVC did not improve blastocyst development. However, supplementation of IGF-I alone or combination with leptin could have a significant impact on early embryonic development resulting in a higher cleavage rate, the embryos passing 8-16 cell stages and decreasing the TUNEL-positive (apoptotic nuclei) per embryos in the blastocyst stage and altering the expression some of the developmentally important genes. These data suggest that leptin and IGF-I have a putative effect on the developing bovine embryos in vitro, and that there are conflicting literature results on the effects of leptin on embryo development. Thus, further research is needed to delineate the mechanisms by which leptin affects embryo development.

\section{Acknowledgements}

Authors would like to thank Mr. Brad Haley for help in obtaining bovine ovaries and Mr. Peter Crump for statistical analysis of the data. Research was supported by the University of Wisconsin-Madison College of Agriculture and Life Sciences, and by Mississippi Agriculture Forestry and Experiment Station, USA. A. Kaya was supported by IDB and by University of Selcuk, Konya, Turkey.

\section{References}

Arias-Alvarez M, Bermejo-Alvarez P, GutierrezAdan A, Rizos D, Lorenzo P, Lonergan P. 2011. Effect of leptin supplementation during in vitro oocyte maturation and embryo culture on bovine embryo development and gene expression patterns. Theriogenology, 75:887-896.

Barb C. 1999. The brain-pituitary-adipocyte axis: role of leptin in modulating neuroendocrine function. $J$ Anim Sci, 77:1249-1257.

Block J, Drost M, Monson R, Rutledge J, Rivera R, Paula-Lopes F, Ocon O, Krininger C, Liu J, Hansen P. 2003. Use of insulin-like growth factor-I during embryo culture and treatment of recipients with gonadotropin-releasing hormone to increase pregnancy rates following the transfer of in vitro-produced embryos to heat-stressed, lactating cows. J Anim Sci, 81:1590-1602.

Boelhauve M, Sinowatz F, Wolf E, Paula-Lopes FF. 2005. Maturation of bovine oocytes in the presence of leptin improves development and reduces apoptosis of in vitro-produced blastocysts. Biol Reprod, 73:737-744.

Brill A, Torchinsky A, Carp H, Toder V. 1999. The role of apoptosis in normal and abnormal embryonic development. J Assist Reprod Genet, 16:512-519.

Byrne A., Southgate J, Brison D, Leese H. 1999. Analysis of apoptosis in the preimplantation bovine embryo using TUNEL. $J$ Reprod Fertil, 117:97-105.

Christians E, Campion E, Thompson EM, Renard JP. 1995. Expression of the HSP 70.1 gene, a landmark of early zygotic activity in the mouse embryo, is restricted to the first burst of transcription. Dev Cambridge 121:113-113.

Cioffi JA, Van Blerkom J, Antczak M, Shafer A, Wittmer S, Snodgrass HR. 1997. The expression of leptin and its receptors in pre-ovulatory human follicles. Mol Hum Reprod, 3:467-472.

Craig JA, Zhu H, Dyce PW, Wen L, Li J. 2005. Leptin enhances porcine preimplantation embryo development in vitro. Mol Cell Endocrinol, 229:141-147.

Edwards JL, Ealy AD, Monterroso VH, Hansen PJ. 1997. Ontogeny of temperature-regulated heat shock protein 70 synthesis in preimplantation bovine embryos. Mol Reprod Dev, 48:25-33. 
Fedorcsák P, Storeng R. 2003. Effects of leptin and leukemia inhibitory factor on preimplantation development and STAT3 signaling of mouse embryos in vitro. Biol Reprod, 69:1531-1538.

Garcia M, Amstalden M, Williams S, Stanko R, Morrison C, Keisler D, Nizielski S, Williams G. 2002. Serum leptin and its adipose gene expression during pubertal development, the estrous cycle, and different seasons in cattle. J Anim Sci, 80:2158-2167.

Herrid M, Nguyen VL, Hinch G, McFarlane JR 2006. Leptin has concentration and stage-dependent effects on embryonic development in vitro. Reproduction, 132:247-256.

Jia Z, Zhang J, Wu Z, Tian J. 2012. Leptin enhances maturation and development of calf oocytes in vitro. Reprod Domest Anim, 47:718-723.

Jousan F, Hansen P. 2004. Insulin-like growth factor-I as a survival factor for the bovine preimplantation embryo exposed to heat shock. Biol Reprod, 71:1665-1670.

Kamalamma P, Kona S, Chakravarthi VP, Kumar AS, Punyakumari B, Rao V. 2016. Effect of leptin on in vitro development of ovine preantral ovarian follicles. Theriogenology 85: 224-229.

Kaneda M, Okano M, Hata K, Sado T, Tsujimoto N, Li E, Sasaki H. 2004. Essential role for de novo DNA methyltransferase Dnmt3a in paternal and maternal imprinting. Nature, 429: 900-903.

Kawamura K, Sato N, Fukuda J, Kodama $H$, Kumagai J, Tanikawa H, Nakamura A, Tanaka T. 2002. Leptin promotes the development of mouse preimplantation embryos in vitro. Endocrinology, 143:1922-1931.

Kendall N, Gutierrez C, Scaramuzzi R, Baird D, Webb R, Campbell B. 2004. Direct in vivo effects of leptin on ovarian steroidogenesis in sheep. Reproduction, 128:757-765.

Khaki A, Batavani R, Najafi G, Tahmasbian H, Belbasi A, Mokarizadeh A. 2014. Effect of leptin on in Vitro nuclear maturation and apoptosis of buffalo (Bubalus bubalis) oocyte. Int J Fertil Sterl, 8:43.

Kšiňanová M, Čikoš Š, Babel'ová J, Šefč́́ková Z, Špirková A, Koppel J, Fabian D. 2017. The Responses of Mouse Preimplantation Embryos to Leptin In Vitro in a Transgenerational Model for Obesity. Front Endocrinol (Lausanne), 8:233.

Latham KE, Schultz RM. 2001. Embryonic genome activation. Front Biosci, 6:D748-759.

Lonergan P, Khatir H, Piumi F, Rieger D, Humblot P, Boland M. 1999. Effect of time interval from insemination to first cleavage on the developmental characteristics, sex ratio and pregnancy rate after transfer of bovine embryos. J Fertil Sterl, 117:159-167.

Memili E, First NL. 1999. Control of gene expression at the onset of bovine embryonic development. Biol Reprod, 61:1198-1207.

Misirlioglu M, Page G, Sagirkaya H, Kaya A, Parrish J, First N, Memili E. 2006. Dynamics of global transcriptome in bovine matured oocytes and preimplantation embryos. Proc Natl Acad Sci, 103:18905-18910.

Neuber E, Powers R. 2000. Is the mouse a clinically relevant model for human fertilization failures? Hum Reprod, 15:171-174.

Panda BSK, Pandey S, Somal A, Parmar MS, Bhat IA, Baiju I, Bharti MK, Sai Kumar G, Chandra V, Sharma GT. 2017. Leptin supplementation in vitro improved developmental competence of buffalo oocytes and embryos. Theriogenology. 98:116-122.

Parrish J, Krogenaes A, Susko-Parrish J. 1995. Effect of bovine sperm separation by either swim-up or Percoll method on success of in vitro fertilization and early embryonic development. Theriogenology, 44:859-869.

Paula-Lopes FF, Boelhauve M, Habermann FA, Sinowatz F, Wolf E. 2007. Leptin promotes meiotic progression and developmental capacity of bovine oocytes via cumulus cell-independent and-dependent mechanisms. Biol Reprod, 76:532-541.

Pfaffl MW. 2001. A new mathematical model for relative quantification in real-time RT-PCR. Nucleic Acids Res, 29:e45-e45.

Pfaffl MW, Horgan GW, Dempfle L. 2002. Relative expression software tool (RESTC) for group-wise comparison and statistical analysis of relative expression results in real-time PCR. Nucleic Acids Res, 30:e36-e36.

Prelle K, Stojkovic M, Boxhammer K, Motlik J, Ewald D, Arnold GJ, Wolf E. 2001. Insulin-Like Growth Factor I (IGF-I) and Long R3IGF-I Differently Affect Development and Messenger Ribonucleic Acid Abundance for IGF-Binding Proteins and Type I IGF Receptors in in Vitro Produced Bovine Embryos 1. Endocrinology, 142:1309-1316.

Rizos D, Gutierrez-Adan A, Perez-Garnelo S, De La Fuente J, Boland M, Lonergan P. 2003. Bovine Embryo Culture in the Presence or Absence of Serum: Implications for Blastocyst Development, Cryotolerance, and Messenger RNA Expression 1. Biol Reprod, 68:236-243.

Sagirkaya H, Misirlioglu M, Kaya A, First NL, Parrish JJ, Memili E. 2006. Developmental and molecular correlates of bovine preimplantation embryos. Reproduction, 131:895-904.

Swain JE, Dunn RL, McConnell D, GonzalezMartinez J, Smith GD. 2004. Direct effects of leptin on mouse reproductive function: regulation of follicular, oocyte, and embryo development. Biol Reprod, 71:1446-1452.

van Tol HT, van Eerdenburg FJ, Colenbrander B, Roelen BA. 2008. Enhancement of Bovine oocyte maturation by leptin is accompanied by an upregulation in mRNA expression of leptin receptor isoforms in cumulus cells. Mol Reprod Dev, 75:578-587.

Wrenzycki C, Herrmann D, Carnwath J, Niemann H. 1999. Alterations in the relative abundance of gene transcripts in preimplantation bovine embryos cultured in medium supplemented with either serum or PVA. Mol Reprod Dev, 53:8-18.

Wrenzycki C, Herrmann D, Lucas-Hahn A, Korsawe K, Lemme E, Niemann H. 2004. Messenger RNA expression patterns in bovine embryos derived from in vitro procedures and their implications for development. Reprod Fertil Dev, 17:23-35. 